\title{
Green pod culture and rapid micropropagation of Dendrobium chrysanthum Wall. - a horticultural and medicinal orchid
}

Kalyan Kumar De, Sudipta Majumdar, Ramnath Sharma, Bibaychana Sharma

Department of Botany

Darjeeling Govt. College P.O. \& Dist. Darjeeling 734101, West Bengal, India

\section{RETRACTION}

The whole article: K.K. De, S. Majumdar, R. Sharma and B. Sharma. Folia Horticulturae 2006, 18/1: 81-90 is retracted on Author's request.

The Author states that photographs in the article were wrong and inserted by a mistake. They presented other Dendrobium species and thus were not adequate to the article content. Additionally, parts of descriptive text and some photographs were copied from their another published paper. So it is an evidence of textual copying and the whole article is confusing to readers. For these reasons the article is retracted in full.

Decision issued 5 Sept 2013 by Rafal Baranski, Editor-in-Chief 